\title{
LA FANTASÍA, FUENTE DE LA HISTORIA
}

\author{
Luis Pérez Ochando \\ Universitat de València \\ Elena Monzón Pertejo \\ Universitat de València
}

Hubo un momento de la Historia en el que inventamos el futuro. El tiempo dejó de ser entonces esa meseta interminable de días sucediéndose idénticos a sí mismos, un erial que se alargaba desde el fin del tiempo de los héroes hasta el Apocalipsis de los días. Hubo un día en que descubrimos que mañana podría ser diferente del presente, que podría haber incluso distintas formas del mañana; pero dichas formas, en razón de su diversidad, no podían ser descubiertas, sino inventadas. El futuro no se desentierra, se fabrica, se imagina, se construye; para llegar a esa conclusión fue necesario, sin embargo, excavar y excavar en el pasado.

La modernidad, que inventó el futuro, inventó también el pasado. Fueron precisas legiones de exploradores y cartógrafos, eruditos y arqueólogos, historiadores y geógrafos, para sondear el pasado y concebir una Historia anfractuosa, con cimas, declives y fallas. La mirada humana, anclada a un presente sin remedio, deseaba ampliar su horizonte en sendas direcciones del tiempo conocido y, sin embargo, para el empeño sólo disponía de la permanencia de las ruinas. Paradójicamente, tanto el futuro como el pasado se construyen con los escombros del presente. Concebimos el resto del tiempo con ruinas varadas y con valores actuales: buscando las sombras fugitivas del ayer y del mañana, proyectamos sobre ellos los fantasmas que nos rondan. En Metrópolis (Fritz Lang, 1927), Maria es una joya de art decó, los rascacielos evocan a la escuela de Chicago, las danzas de Yoshiwara al desenfreno del cabaré; pero también el industrialismo y el conflicto de clases de la República de Weimar reverberan en Metrópolis, donde las manos -el proletariado- y el cerebro -el capital- esperan a un mesías capaz de aunar sus corazones. La manera en que cada época imagina el futuro es un reflejo de cómo imagina el pasado y no es extraño, incluso, que las figuraciones del futuro se construyan apilando estratos de otras eras: en Ghost in the Shell (Kōkaku Kidōtai, Mamoru Oshii, 1995) cables, hologramas y luces de neón estrangulan los antiguos santuarios de Kowloon; en Metrópolis, el laboratorio de Rotwan es una cripta medieval, una catedral gótica se yergue en el corazón de la capital del porvenir. Como descubriremos a lo largo de este número de Sai- 
tabi, uno de los intereses que ocupa a los investigadores de la fantasía es la continuidad entre el imaginario del pasado y del futuro o, dicho de otro modo, la manera en que recurrimos a la historia para darle un rostro al porvenir.

No es mera cuestión de raccord entre eras, tampoco un ejemplo más de cómo el posmodernismo canibaliza los estilos del pasado, sino la estrategia a través de la que afrontamos el shock del porvenir. El futuro es tierra incierta, peligrosa; mejor amarrarla sembrándola con pecios del presente y el pasado; mejor concebir continuidades que afrontar el hecho de que todo pueda ser distinto alguna vez, que el marco conceptual que nos da sentido pueda desvanecerse, arrastrándonos consigo. Rastrear las permanencias visuales y temáticas en los textos nos permite, en consecuencia, descubrir los asideros de nuestro entendimiento del presente: conquistaremos otras galaxias, pero seguiremos creyendo en Dios; el mundo acabará, pero seguirá habiendo capitalismo. Como argumentaba Fredric Jameson, la ciencia ficción nos devuelve el presente no en su complejidad inabarcable, sino reescrito como recuerdo y, por tanto, presentado como un relato en el que lo relevante -aquello que tendrá consecuencias- despunta sobre el ruido.

Así, lo que nos interesa como historiadores no es sólo el nudo visible entre los tiempos. El énfasis, en cambio, debe ponerse en el acto imaginario, en esa fabulación a través de la que ponemos en escena -"érase una vez...", "en una galaxia muy lejana..."- las aspiraciones y temores de cada periodo. Las implicaciones de cara a la ciencia ficción resultan claras: al igual que La guerra de los mundos de H. G. Wells invierte los términos del imperialismo británico; la versión fílmica de Spielberg nos habla del deseo, ya imposible, de volver a sentirse seguros y en familia después del 11S. La fantasía histórica, por su parte, proyecta esos mismos anhelos y miedos hacia el tiempo de los mitos, el alba de los sueños en que diosas y monstruos se confunden con mujeres y hombres.

La fantasía, el terror y la ciencia ficción constituyen una fuente de información privilegiada para la comprensión de la Historia, no a través de sus desechos materiales, sino a través de sus sueños vivos. Podemos coleccionar los sombreros de los victorianos, revisar sus diarios y legajos de nóminas, catalogar sus vías férreas, inventariar hasta el último jarrón traído de Arabia por Lord Leighton; sin embargo, nada nos dirá más de su mundo interior, pulsional y secreto, que las páginas de Drácula o que el viaje de Marlow en El corazón de las tinieblas. Desentrañar estos sueños vivos reclama, sin embargo, una comprensión tanto de la época como de los engranajes de los textos, tanto un análisis de su contexto, como de la dinámica del género que los engloba. Para entender Blade Runner (Ridley Scott, 1892) no basta con estudiar la teoría posmodernista; debemos conocer también la obra de Philip Dick y la ciencia ficción estrenada en el periodo; es preciso, sobre todo, examinar cada plano y 
preguntarnos qué desean los replicantes. Si escuchamos atentamente, descubriremos que los sueños de los androides no son sino los nuestros y que éramos nosotros quienes necesitaban fotografías familiares y animales de compañía para creer, al salir del trabajo, que todavía estamos vivos.

Entender la fantasía no debe ser sólo un campo legítimo de estudio, sino también un objetivo prioritario de la Historia, pues en la medida en que la fantasía siga considerándose mero entretenimiento, seguiremos dejando el relato de nuestro pasado y nuestro futuro en manos de intereses transnacionales. Por el contrario, la escritura de la Historia persigue la verdad, es una postura ética y, por ende, política. Todavía en 1995, Brian Altebery exclamaba: "La política de la fantasía: ¡qué asunto tan peculiar! No es difícil ver una conexión entre la fantasía y los arquetipos, o entre la fantasía y la ética, o ver la fantasía como una expresión de la metafísica, pero ¿qué tiene que ver la política con ella?”.

La negación del contenido ideológico de los productos culturales no sólo es un planteamiento ignorante, también es nocivo. La idea, sin embargo, es repetida como un mantra tanto por las industrias culturales como por la crítica más zafia. En ello consiste, ahí radica, el poder social de tales productos, en su capacidad de presentarse como un entretenimiento inofensivo, ideológicamente neutro, con valores ya no históricos y contingentes, sino netamente universales. Hoy resulta inevitable ver la Guerra Fría en La tierra contra los platillos volantes (Earth vs. the Flying Saucers, Fred F. Sears, 1956), con sus naves espaciales reventando el Capitolio y sus invasores infiltrados entre los oficiales; sin embargo, debemos estirar nuestro interrogante hasta el presente. Debemos estirarlo hasta tornarlo exclamación, asombrarnos por el grado en que las fantasías que consumimos responden y refuerzan el pensamiento dominante.

Pensemos, por ejemplo, en cómo la tortura deviene cotidiana en la ficción posterior al 11S, en cómo pasa de tabú a mal necesario - con la necesidad que impone encontrar una bomba, descubrir el paradero del enemigo o, simple y llanamente, vengar una afrenta-; pensemos, por ejemplo, en cómo la ficción apocalíptica o distópica se ha vuelto dominante y en cómo ello nos habla de nuestra propia incapacidad para concebir que del hoy pueda arraigar ya nada. Hubo un tiempo en que descubrimos el futuro, hoy apartamos la vista de nuestra creación. Es nuestro hijo inmundo, nuestro Frankenstein desencadenado. Ya no queremos conocerlo, ni siquiera mirarlo. Hoy tememos futuros totalitarios, cámaras por todas partes, repúblicas de burócratas -o, diría Marx, de hombres petrificados-, policías con poderes judiciales, ciudades sumergidas y dunas sepultando rascacielos.

Hay, sin embargo, cobardía en ello, una parálisis del ingenio, una incapacidad de concebir que el futuro pueda ser algo distinto del presente. Tal es el cargo que George Orwell presentaba contra el ensayo de James Burnham titu- 
lado The Managerial Revolution, en un momento, 1940, en el que, con los nazis campando por Europa, lo preciso era pensar que su barbarie burocrática podía derrotarse, que podía incluso revertirse. Si hemos puesto de relieve, al principio de este texto, que el futuro es una invención y no un descubrimiento es porque ello nos hace conscientes de nuestra capacidad para cambiarlo. Ciertamente, cuanto más conocemos el presente, más improbable se nos antoja quebrantarlo. Es la paradoja de Marx y de Foucault: el Marx que escribe $E l$ manifiesto comunista no es el mismo que escribe El capital; cuanto más precisa es la descripción del paradigma foucaultiano, más encerrados nos sentimos. Sin embargo, la ventaja de la fantasía es que, por más que reproduzca pensamientos del pasado y del presente, también nos ofrece la posibilidad de transformarlos. La mera presencia de estos pecios del hoy y del ayer no es sino el subterfugio que nos resguarda del trastorno del mañana. Echémoslos abajo, ya no nos hacen falta.

Estudiar, desde la Historia, las fantasías de pasado y de futuro planteadas en cada época nos permite no sólo comprender mejor el sentir de cada periodo, sino también comprender su naturaleza artificial y que, por tanto, podemos soñar otros mañanas. 